\title{
Analysis of Adoption of Mobile Banking for Financial Inclusion in Rural India
}

\author{
Punitha Ponnuraj ${ }^{1}$, Dr. Manasa Nagabhushanam ${ }^{2}$ \\ ${ }^{1}$ Research Scholar, University of Mysore, ISBR Research Centre, Bangalore \\ ${ }^{2}$ Professor,ISBR Research Centre
}

\begin{abstract}
The main vision of the Indian government for the past few decades is to achieve sustainable development and inclusive growth. Growth is inclusive only when formal financial services are accessible to the weaker sections and low income groups at an affordable cost. Increasing bank branches is not cost efficient and the only way forward is technology. Given the rising mobile phone usage in the country, mobile banking has a great potential for enabling financial services to the unbanked and under banked in rural areas. This paper conducts a systematic literature review on the evolution of mobile banking and its adoption across India. It aims to focus on understanding the reasons for failure of Indian government's initiatives to implement mobile banking, identifying the barriers for the adoption of mobile banking in rural areas and suggesting ways to increase the utilization of mobile banking for the interest of the financially underserved rural population. The main objective of this paper is to establish a working relationship between mobile banking and financial inclusion. The conclusions drawn from the literature state that mobile banking has a huge potential to change the way people in rural areas transact and save money. Therefore, there is a scope for future researchers to study and analyse various mobile banking models and their impact on rural India.
\end{abstract}

Keywords: Financial Inclusion, Mobile banking, Rural India, Evolution of banking, Payments bank

\section{Introduction}

India has the second largest financially excluded poor in the world with more than half of its population considered as financially underserved. At the same time, India is one of the fastest growing markets for mobile phones. According to TRAI's monthly Indian Telecom subscription report in Feb 2017 , total mobile subscriber base has reached 1100 million of which 461.05 million subscribers are from rural India. Thus for countries like India where sizeable proportion of households do not have a bank account and large unbanked sections of population reside in the villages, the banking brick and mortar network is not cost efficient and the only way forward is to leverage technology. Given the rising mobile phone usage in the country, mobile banking (also known as M-Banking) has a great potential for enabling financial services to the unbanked and under banked, particularly in rural areas. Government of India has identified this opportunity as early as 2008 and has formulated a number of initiatives to target the mobile banking services at the rural population.

\section{Problem Statement}

A lot of measures have been taken to harness the potential of mobile banking from setting up of IMPS/SMS/USSD channels in 2008 \& Business correspondents in 2010 to setting up of payment banks recently. Yet, the percentage of under banked and unbanked population in rural areas remain high.Identifying the adoption barriers and the exact financial needs of the rural population would help the banks to tune their products and servicesand would help tobridge the gap between demand and supply.

\section{Research Questions}

This paper will aim to answer the following research questions based on an extended review and analysis of literature collected.

RQ1: What are the mobile banking products or services currently available for the rural population?

RQ2: What are the major banking needs of the rural population (Remittance services/Savings etc.)?

RQ3: Is there a gap between the products and services offered and the banking needs?

RQ4: Does mobile banking have a potential to offer banking services and products for the under banked population in rural areas?

\section{Importance of Research Questions}

This conceptual paper is noteworthy because it will try to explore the major banking needs of people in rural areas Vs how mobile banking is targeted at the unbanked in rural areas through extensive review of literature. This will help to identify factors influencing the adoption of mobile banking by the rural populationand make recommendations for future research.

\section{Research Methodology}

The methodology followed for analysis will be analytical review of literature. This paper analyses the background of mobile banking and how it can benefit therural population based on conceptual and empirical studies conducted by many researchers in India and other developing countries. The research is focused on exploringthe various mobile banking products and services aimed at rural population to serve the unbanked and identifying the reasons of their lesser adoption. The results are summed up in the conclusion. 


\section{Analysis and Discussion of Literature}

Mobile banking in rural areas and its impact on financial inclusionin India has been widely discussed by many researchers.

\section{Mobile Banking in India - Current Scenario USSD and IMPS:}

The RBI report "Report of the Technical Committee on Mobile Banking" (2014, India) describes in detail the overview of mobile banking and its current scenario in India. It explains the various mobile banking channels offered such as SMS, USSD, IMPS and mobile banking applications etc from 2008. These range from ubiquitous voice and SMS channels to more sophisticated means such as software applications or web browsers. It is also mentioned that the Governments, both at the central and the state levels, have also been taking measures in encouraging electronic payments and receipts, such as, electronic benefit transfers and e-mode of transactions for their receipts and payments.

The RBI Report on "Customising mobile banking in India: issues \& challenges" (2012, India) speaks about IMPS and the customised USSD (Unstructured Supplementary Service Data) launched by NPCI and Mobile linked Kisan Credit Cards for farmers having KCC accounts with the Pallavan Grama Bank (an RRB sponsored by the Indian Bank). The $\mathrm{m}$-KCC using mobile technology enables farmers to carry out purchase of agricultural inputs in a cash-less manner. All transactions are carried out through mobile phones of farmers and vendors registered with the bank and the technical service provider (TSP). This enables the farmers to buy agriculture inputs by putting through the transactions through a mobile phone enabled system linked to the banks CBS. The major advantage of USSD is that the IMPS could become accessible even through low-end hand-sets.

\section{Direct Transfer of government benefits usinq JAM initiative (Jan Dhan, Aadhar and Mobile) \\ NREGS payments - ALW and Zero Mass foundation \\ U Jumani on his paper "A little world - Facilitating safe and efficient M-banking in rural India" (2010) has explained in detail about the Direct benefit transfer schemes by Indian Government. As a spin-off to the RBI's Financial Inclusion Project, ALW began a pilot project for the State Bank of India (SBI) to provide banking transactions in the rural villages of Aizwal (Mizoram), Madek (Andhra Pradesh) and Pithoragarh (Uttarakhand). MNREGS (Zeromass and SBI, mpesa and Vodafone in Odisha etc). ZMF has enrolled over four million people for standard bank accounts. More importantly, besides facilitating the opening of bank accounts, ALW's technology platform enabled corruption- free distribution of government funds such as NREGA Scheme of Government for Rural Areas. Customers can directly access their accounts through the mobile phone at customer service points (CSPs) using their finger prints via biometric identification.}

\section{Social Security pensions and NREGS payments - Vodafone and Mpesa \\ Vodafone in partnership with the Government of Haryana has facilitated mobile-based disbursement of monthly social security pension through M-Pesa. Vodafone's mobile money}

transfer and payment service has been carried out as a pilot initiative, covering 868 beneficiaries at five villages in Karnal and Mahendragarh districts in Haryana. Operated under the Government of India's pension scheme, Vodafone's M-Pesa has been identified as the most suitable partner to facilitate digital transfer of financial disbursements to pensioners in Haryana, offering a safe and secure mechanism to transfer funds.Also, handicapped old age pension schemes, Student Scholarships, LPG subsidies have been paid via direct benefit transfers.

Vishal R. Sandanshive and Dr. Vivek V. Katdar has detailed on their paper "Analysis of In-Principle License Entities to Act as Payments Banks: Financial Inclusion Perspectives"about M-pesa by Vodafone India Ltd in partnership with ICICI Bank Ltd. It offers services such as utility bill payments and recharge options, money transfer accounts via M-Pesa agents or business correspondents. In November 2011, HDFC Bank and Vodafone India launched a partnership and technology solution that enabled customers to perform basic banking transactions on mobile phones, including the ability to deposit and withdraw cash at specific Vodafone branches. In a similar way, Airtel partnered with Axis Bank in May 2012 to deliver a no-frills savings bank account of Axis Bank on Airtel's mobile platform.

\section{Business correspondents:}

Yes Bank (2012) reported that the Indian model is based on the supposition that the use of mobile phones for banking in financial inclusion cannot become a viable proposition on a standalone basis if the purpose is to achieve meaningful financial inclusion. For financial inclusion, mobile payments have to be provided as a package along with other products and services. The report points out that this package can be offered only by the companies that can provide add-on services like emergency and entrepreneurial credit, saving facilities, other products and services such as insurance, besides remittances and in India, non-bank companies are often thought not to be able to offer a range of financial products, which are important from the point of view of financial inclusion (FI). The report stresses on the fact that with an extensive network of retail outlets, even in remote places where there is no bank branch, mobile operators can partner with banks as business correspondents to ensure that mobile banking reaches the last mile in view of its spread and usage; and that a healthy partnership between banks and mobile services providers (MSPs) augur well for the FI process. The report identifies that in consideration of the above points, India adopted a bank-led full financial inclusion model with Business Correspondents.

Puneet Chopra, Manoj Sharma \& Mukesh Sadana (2012) studied the BC model and reported that the scheduled commercial banks including Regional Rural Banks (RRBs) and Local Area Banks (LABs) were allowed to engage Business Correspondents (BCs) and the goal was to provide nearly 74,200 defined villages across India with bank or BC facilities by March 2012. The transactions were put through ICT devices (handheld device/mobile phone) that are seamlessly integrated to the Core Banking Solution (CBS) of the bank.

\section{Volume 6 Issue 7, July 2017




\section{International Journal of Science and Research (IJSR) \\ ISSN (Online): 2319-7064}

Index Copernicus Value (2015): 78.96 | Impact Factor (2015): 6.391

According to the CGAP report on "Business correspondents: A pathway to financial Inclusion" (2010), approximately 1520 banks piloted the BC model for expanding their operations and SBI recruited as many $\mathrm{BCs}$ as possible. Among private banks, ICICI Bank and HDFC had taken the lead in making use of the scheme. Several other banks such as Indian Bank, Canara Bank, Union Bank of India, Corporation Bank, Punjab National Bank, Oriental Bank of Commerce, Andhra Bank, Axis Bank have also tested the model.

The study reported that though ambitious target for outreach was achieved, and by March 31, 2012, some form of banking touch point was made available in 74,199 villages, according to RBI's annual report 2011-12, over $75 \%$ of the no-frills-accounts are dormant.

Research done by Enclude and Grameen Foundation shows that the banks have used the BC option to open large numbers of 'No Frills Accounts' in response to a policy push from the Government of India. In some cases this has also been combined with channelling government payments (G2P) such as NREGS, Pensions and other social payments. In a few cases, the focus has been on extending credit either in partnership with an MFI or through a relationship with a SHG Federation or network. The big difference in performance and partnerships appears to be between those $\mathrm{BC}$ efforts that are account and savings focused, versus those that focus on delivering credit services. This is detailed in their report "Discussion papers on Business correspondents in India" (2013)

Naveen Kolloju on his paper "Business Correspondent Model vis-à-vis Financial Inclusion in India: New practice of Banking to the Poor" (2014) has explained that though this delivery service helps to address access issues, not enough attention is being paid to producing customer-centric designs for products and services. Though access of financial services is available at doorstep, most of the services offered don't fit a client's need. Products need to be tailored to take customer behaviour into consideration.

Also, Business correspondent agents (BCAs), a face of the bank, delivering services to the consumers at the grass root level, find the business model flawed and failing to provide them remuneration commensurate with their efforts or investments. The result is high levels of de-moralization, demotivation and attrition amongst agents across the country. The business models being implemented by banks lack analysis of, or focus on, the preferences and expectations of poor consumers, who want differentiated services (in terms of products on offer, service quality, security, protection and so on) and are willing to pay for these.(Puneet et al 1986).

The report on "Business Correspondent model - A layered approach to Banking " by CGAP (2014) mentions that design aspects such as product labelling and consumer education are largely missing from many of these outreach programs to lowest income customers. The current programs also have done little to provide incentives to customers above the usual basic savings and bank deposit accounts, previously called no-frill accounts, and electronic benefit transfers. Also, most banks have not really given the $\mathrm{BC}$ arrangement the kind of push it requires considering its future potential.

Charan Singh in his paper "Financial Inclusion In India : Select issues" (2015), mentions that the low number of transactions due to limited product suit, lack of interest by people and technology hiccups has made the business unsustainable for many BCs which is affecting the scaling of the current models

\section{Case of EKO - A successful BC}

While BC model largely failed, there were a few cases where the Business correspondents had some success, when tailored to the needs of the rural population. One such case is Eko. Eko is a Business Correspondent and Technology Service Provider to multiple banks which has partnerships with few of the biggest banks in India like State Bank of India (SBI), ICICI Bank, Yes Bank. It leveraged on existing retail shops, telecom connectivity and banking infrastructure to extend branchless banking services to a common man. EKOcounter offered one stop recharge facility for all leading mobile and DTH operators in India. EKO offered cash management services, namely cash collection and cash disbursal services to Government Enterprises, Micro Finance Institutions and Large, Medium and Small Scale enterprises. Its remittance product (Tatkal) and its mini savings productwere a huge success.

Mudita Tiwari and Deepti K.C on their paper "'" (2012,India ) mention that the positive perceptions about the effects of mobile banking in the daily lives of EKO mobile banking users is an encouraging sign about its potential for financial inclusion of large numbers of the underserved and unbanked low income households in both rural and urban India. While customer acquisition was fairly easy when the mobile money service was provided for free, a midway introduction of transaction fees led to almost a third of existing users dropping out of the services. The inactive lowincome users expressed their keenness to restart using mobile money in the future subject to a reasonable pricing policy by the service provider.

\section{Payment Banks}

Reserve Bank placed on its website, a policy discussion paper "Banking Structure in India - The Way Forward". One of the observations in the discussion paper was that there is a need for niche banking and differentiated licensing in India. Subsequently, RBI licensed payments banks which would offer financial services to the hitherto excluded segments of the population and to meet credit and remittance needs of small businesses, unorganized sector, low income households, farmers and migrant work force.Currently 8 firms - Aditya Birla Nuvo Limited, Airtel M Commerce Services Limited, Department of Posts, Fino PayTech Limited, National Securities Depository Limited, Reliance Industries Limited and Vodafone m-pesa Limited are licensed by the RBI to launch payments banks.

Airtel launched its payments bank in November 2016 and rolled out its pilot services in Rajasthan. With over 10,000 saving accounts opened within two days of it going live, a 


\section{International Journal of Science and Research (IJSR) \\ ISSN (Online): 2319-7064}

Index Copernicus Value (2015): 78.96 | Impact Factor (2015): 6.391

majority of customers living in the semi-urban and rural areas have been benefited. India Post Payments Bank (IPPB) approved by the Union cabinet will function as a public limited company under the department of posts. IPPB launched in January 2017, primarily focuses on products of financial inclusion, direct benefit transfer, door step banking. With a $100 \%$ government equity and a total corpus amount of Rs.800 crore an unrivalled network of more than 150,000 branches, of which almost 140,000 are in India's rural hinterland is considered to be a game changer in rural banking.

Jane K Winn on his paper "Mobile Payments and Financial Inclusion: Kenya, Brazil and India as Case Studies" (2015) mentions that the early attempts to regulate mobile payments and business correspondents erected regulatory and technological barriers to their adoption, but the new "payment bank" regulatory framework may finally have removed those barriers for good. He also mentions that in partnership with the banking industry and to promote competition, India has created an open, public platform for clearing and settlement of electronic payments, and has begun using the new RuPay card network together with the new Aadhaar national identity scheme to deliver direct benefit transfers to the poor.

\section{Banking Needs of the Rural Population}

Financial services such as secure savings, credit, money transfer and insurance play an important role in rural development. Confronted with the lack of access to formal financial system many households, farmers and small entrepreneurs rely on informal ways of accessing financial services.

Inforesources report on "Accessing Financial Services in Rural Areas"(2010) explains the type of financial products and services needed in rural areas in developing nations. Savings and insurance schemes assist the rural population in reducing vulnerability to risks, planning more reliably for the future and saving for upcoming investments, covering unexpected expenses as well as smoothing out irregular income flows such as income depending on agricultural cycles. Loans for investments and working capital are crucial elements that enable rural entrepreneurs to make investments, seize economic opportunities, and purchase agricultural inputs and working capital. Money transfer services make it possible for people who leave rural areas to work in cities or abroad to send home their remittances safely and at reasonable costs.

Dileep $S$ describes the financing needs of rural population in India in his paper"A Study on Indian Rural Banking Industry-Issues and Challenges "(2013) that income of people in rural areas tend to be small, irregular, and unreliable and they need the fullarmoury of intermediating mode such as saving up for future spending, taking advances against future savings, and building cash reserves that can be called on at any time. The poor need a wide range of financial services-from small advances to tide over consumption needs to loans for investment purposes to longterm savings that help them manage life-cycle needs.

\section{Reasons for Slow Adoption}

Sanjeev Kumar Gupta (2013) in his study found that the main reason for slow inclusion by banks is the absence of delivery model and products designed to satisfy the low income families. He points out that the provision of uncomplicated, small, affordable products will help to bring the low income families into the formal financial sector.

Ardhendu Shekhar Singh (2015) in his paper "Role of mobile banking in Financial Inclusion" mentions that Customers are unaware about functioning of financial system at large and specifically products available to them. Even if they are aware, accessing them is costlier because of higher transaction costs involving information cost, travelling cost, and opportunity cost. Many a time even products don't match their needs, forcing them to not join the system. Apart from this, majority of them are engaged in an occupation where regular income is not guaranteed; thus making the existing financial system unsuitable to address their needs/ concerns. He also adds that in addition to these, behavioural constraints like fear of the system, lack of trust etc. comes into picture to work as a hindrance to creating an inclusive financial environment. When it comes to the supply side ie the banks, they don't have products matching the need of customers, many a times because of lack of information about them. Even when they are aware about the needs, products are not feasible. Serving to these customers are usually costlier because of higher information cost, and accessing cost (geographical constraints).

Sanjeev Kumar (2013) has mentioned in his research paper titled "Indian Economy: Banking the unbanked" that Banks have limitations to reach directly to the low income consumers and the use of technology and using economies of scale will, however bring down the cost of transaction to the banks and it will be a win - win position for both banks and customers.

RBI (2014) reported that the developments in mobile telephony as also the mobile phone density in the country, with over $870 \mathrm{Mn}$ mobile phone subscribers, presents a unique leverage to meet the objectives and challenges of financial inclusion. By harnessing the potential of mobile penetration, large sections of the un-banked and underbanked society can be empowered to become inclusive through the use of electronic payments.

Anil Bhasin, Senior Vice President, of Cisco India has mentioned on his article that being ubiquitous in India, mobile banking when implemented in the right way, will ensure that urban poor and rural populations benefit from services such as receiving credit, payments and transfers, account opening and loan approvals.

\section{Results and Discussion}

The studies conducted in India and other developing countries have been reviewed with the view to answer the three research questions. 


\section{International Journal of Science and Research (IJSR) \\ ISSN (Online): 2319-7064}

Index Copernicus Value (2015): 78.96 | Impact Factor (2015): 6.391

There indeed is a huge need for mobile banking services in rural India

The rural market is still seen by most financial institutions as high-risk, low return, as well as hard to reach. This is especially because expansion of bank into small towns and villages involves high costs and thereby reduce the profitability of banks, thus making branch expansion decision unattractive to the service providing banks. In the demand side, though there are a huge number of government subsidies such as NREGS and cash programs that are meant to encourage development in villages and to access these payments, villagers had to travel for hours to nearby cities in order to visit a bank branch, where the experience is frequently alienating. Thus, distance or time to bank branch increase the effective cost of using financial services as the villagers need to travel miles to a nearby bank. Thus for countries like India where sizeable proportion of households do not have a bank account and large unbanked sections of population reside in the villages, the banking brick and mortar network is not cost efficient and the only way forward is to leverage technology.

There are a lot of mobile banking products currently in place, but only a few cater to the needs of rural India. There is a huge gap between the mobile banking needs of rural Indian population and the products and services available.

The financial needs of rural customers are not just savings and loans but are linked to their life cycle needs, ranging from savings to credit to insurance to remittances. In fact, even the savings and credit products currently offered to rural customers do not entirely meet their needs. Since the people in rural areas earn in small frequent amounts, they need micro-savings and frequent withdrawals which helps them to a save over the long term, as well as manage with unexpected expenditure in the near term. However, current mobile banking products offered do not address these needs. This is one of the major reason for them to transact with the informal sector. Also Rural customers need loans not only for productive purposes but also for consumption, education and emergencies. Though banks offer purpose free loans (personal loans and credit cards) in urban areas quite liberally, in rural areas sanction of such loans is significantly restricted. Therefore, the poor raise these loans through the informal financial system. In addition, larger households need occasional high value micro-enterprise loans for small capital investment. Though banks offer these loans, they require excessive documentation and time-consuming processes which discourage customer applications. Also, there are many rural households which depend on weekly or monthly remittances from their family members who have moved to urban areas. At present, they depend on informal channels to remit the money and consequently either risk the loss of money or pay high transaction fees since many rural branches do not offer seamless remittance services. Thus, there is a huge gap between the mobile banking products offered and needed.

\section{Conclusion}

From the literature review, we can state that mobile banking does have a huge potential for financial inclusion if the barriers for its adoption by rural population in India are removed. The major supply side barriers are found to be (a) The lack of financial products which are in demand (b) Unaffordable products c) high transaction costs d) products which are inconvenient, inflexible, not customized and of low quality e) Non-bank companies being able to offer a range of financial products. Payment banks, the recent major step towards financial inclusion has the potential to remove these supply side barriers. The Department of Posts becoming a payments bank with a pan-India network, access to the government subsidies and cash programs that are meant to encourage development in villages is made very easy.The literature review suggested that mobile operators can partner with banks to ensure that mobile banking reaches the last mile in view of its spread and usage. The telecom companies such as Airtel and Vodafone have already launched wallet services and have demonstrated the success of prepaid recharge cards through kirana stores in a costeffective manner. After payment banks, the RBI will license "small banks", which have to focus loans on small borrowers and not big corporates. Once this happens, nonbank finance companies will become "small banks" and make financial inclusion more complete from the small borrower's point of view. The demand side barriers identified from the secondary research are (a) Low literacy levels, lack of awareness and understanding of financial products, (b) irregular income, (c) frequent microtransactions, (d) Lack of trust in formal banking institutions, cultural obstacles (e.g., gender and cultural values e) selfexclusion because of the fear of refusal to access by the service providers. The review of literature suggests that, these can be removed by organising financial literacy programmes and trainings, credit counselling etc. Mobile banking with its ubiquitous nature, has a huge potential to bring the rural population into formal financial system, when these barriers are removed.

\section{Scope and Limitations}

Firstly the conceptual paper discusses about the current scenario of mobile banking and the reason of its slow adoption. It doesn't discuss the technical and regulatory aspects of mobile banking. Secondly, being a conceptual paper, this study attempts to analyse studies conducted by other researchers where certain errors may have crept up owing to their limitations. Similar errors have been unknowingly borrowed in this paper since the entire conclusion has been based on those studies. Thirdly, the paper focuses mainly on the current scenario of mobile banking and the reason of its slow adoption. It doesn't discuss the technical and regulatory aspects of mobile banking.

\section{References}

[1] Almazán, Mireya, and Jennifer Frydrych. 2015,“Mobile Financial Services in Latin America \& the Caribbean: State of Play, Commercial Models, and Regulatory Approaches."

[2] Jane K Winn. 2015, "Mobile Payments and Financial Inclusion: Kenya, Brazil and India as Case Studies" 


\section{International Journal of Science and Research (IJSR) \\ ISSN (Online): 2319-7064}

Index Copernicus Value (2015): 78.96 | Impact Factor (2015): 6.391

[3] Md. Nur Alam Siddik, Gang Sun, CUI Yanjuan and Sajal Kabiraj. 2014," Financial Inclusion through Mobile Banking: A Case of Bangladesh"

[4] K.Ramesha, D. Bapat and D. Roy. 2014 "Recent Developments

[5] Charan Singh, Akanksha Mittal , Akshay Goenka, Cirigani Rahul Pramod Goud , Karthik Ram, Rathi Vaibhav Suresh, Ravi Chandrakar and Ujjaval Kumar. 2014 "Financial Inclusion in India: Select Issues"

[6] Singh S., 2014, "The Impact and Adoption of Mobile banking in Delhi"

[7] mPay Insights September 2014 - "Translating to Transactions by Deloitte “

[8] Gurpreet Singh Sambhy. 2014 "Study of Mobile Payment Services in India"

[9] RBI (2014), “Annual Report".

[10]RBI (2014a), "Report on comprehensive financial services for small businesses and low Income households" (Chairman: Dr. N. Mor).

[11]RBI (2014b), "Report of the Technical Committee on Mobile Banking" (Chairman: Mr. B Sambamurthy).

[12] Subbiah, Nalini 2014, "Role of Banks in Financial Inclusion"

[13] Telecom Regulatory Authority of India 2014, "Highlights on Telecom Subscription Data"

[14] Joshi, Deepali P. 2014, "Strategy Adopted For Financial Inclusion", Speech, Workshop of Government of Madhya Pradesh.

[15]K., Divya 2014, “A Study On Impact Of Financial Inclusion With Reference To Daily Wage Earners",

[16]RBI 2013, "How the poor manage their finances; A study of the portfolio choices of poor households in Ernakulum district, Kerala"

[17] Srikanth, R. 2013, “A Study on Role of Indian Banks in Reaching Out to the Unbanked and Backward Areas"

[18] Kongkong M. 2012, "Mobile banking Capabilities Required to Serve the Unbanked Market in South Africa"

[19] Korir G.2012, "Factor Influencing Mobile Banking in Kenya: A Case of Kenya Commercial Bank in Garissa"

[20] Pallab S., and Munish M. (2013), "Internet Banking in India - A Perspective on Benefits and Challenges Involved"

[21] Chakrabarty K.C.2013, "Financial Inclusion in India: Journey So Far And the Way Forward', Key note address at Finance Inclusion Conclave Organised by CNBC TV18 at New Delhi.

[22] Crisil Inclusix. 2013, a Report on Index to Measure India's Progress on Financial Inclusion

[23] S.K. Mishra and D. P. Sahoo. 2013 "Mobile banking adoption and benefits towards customers service,"

[24]Dr. Vinod Kumar Gupta, Renu Bagoria, Neha Bagoria.2013, "Mobile banking services as adoption and challenges: A case of Mbanking in India"

[25] Viveinne A. L., 2013, "Mobile Money, Financial Inclusion and Financial Integrity: The South African Case"

[26] Handoo, Jatinder. 2013. "Financial Inclusion 2.0: India's Business Correspondents." Consultative Group to Assist the Poor (CGAP)

[27] Sarkar A.N .2013, "Financial Inclusion Part-II: Fostering Sustainable Economic Growth in India"
[28] Talla J. H., 2013, “An Empirical Study of E-Banking in Cameroon, University of South Africa"

[29] Sharma, A. 2013, Nokia Money. (G. Sambhy, Interviewer) New Delhi, Delhi, India.

[30] Singh, P., \& Bamoriya, P. 2012. "Mobile Banking in India: Barriers adoption and service preferences"

[31] Smart Card Alliance. 2011, "The Mobile Payments and NFC Landscape. A Smart Card Alliance Payments Council"

[32] Indrani Medhi, Aishwarya Ratan, Kentaro Toyama.2012 "Mobile-Banking Adoption and Usage by Low-Literate, Low-Income Users in the developing world"

[33] Mani A. Nandhi.2012," Effects of Mobile Banking on the Savings Practices of Low Income Users - The Indian Experience"

[34] Yes bank 2012 - "Financial Inclusion and Integration through Mobile Payments and Transfer"

[35]2011. "Analysis of mobile banking for financial inclusion in Tanzania" - A Case of Kibaha district council

[36] Beck, T., I. Faye, S. M. Maimbo, and T. Triki. 2011. Financing Africa Through the Crisis and Beyond. Washington, DC: World Bank.

[37] S. M. S. Ahmed, S. J. Rayhan, M. A. Islam and S. Mahjabin. 2011 "Problems and prospects of mobile banking in Bangladesh"

[38] J. Sripalawat, A. Thongmak and A. Ngramyarn. 2011, "M-banking in metropolitan Bangkok and a comparison with other Countries"

[39] Ching Mun Cheah1, Aik Chuan Teo2, Jia Sim3, Kam Hoe Oon4 and Boon In Tan5.2011, "Factors Affecting Malaysian Mobile Banking Adoption: An Empirical Analysis"

[40] Sumanjeet S. (2010), “Accelerating Financial Inclusion through Mobile Phone Technology: Opportunities, Challenges and Policy Options"

[41] International Finance Corporation (World Bank), 2010 "Mobile Banking in Indonesia: Assessing the Market Potential for Mobile Technology to Extend Banking to the UnbankedandUnderbanked,"

[42] Supathanish Termsnguanwong, 2010, "Customers discernment of mobile banking business : Northern Region of Thailand"

[43] Gupta, Sanjeev Kumar 2011, "Financial Inclusion - IT as an enabler"

[44] Nandhi, Mani A. 2010. "Urban Poor and their Money: A Study of Cycle Rickshaw Pullers in Delhi."

[45] Euromonitor International 2010, "Emerging Focus: Emerging market economies drive global growth in mobile connectivity".

[46] Planning Commission. Government of India 2009:-'Broadening Access to Finance (Chapter - 3)" in A Hundred Small Steps: Report of the Committee on Financial Sector Reforms."

[47] Shi Yu. 2009, "Factors influencing the use of Mobile Banking:The case of SMS-based Mobile Banking"

[48] Thullani D., Tofara C., and Langton R., 2009, "Adoption and use of Internet banking in Zimbabwe"

[49] Rangarajan, C (2008) "Report of the Committee on Financial Inclusion", Ministry of Finance, Government of India. 


\section{International Journal of Science and Research (IJSR) \\ ISSN (Online): 2319-7064}

Index Copernicus Value (2015): 78.96 | Impact Factor (2015): 6.391

[50] Government of India (2008), "Committee on Financial Inclusion" (Chairman: Dr. C. Rangarajan).

[51] Vahid, R., \& Habibi, J. (2008). "MPaySmart: A Customer Centric Approach in Offering Efficient Mobile Payment Services."

[52] Laurent Bailly and Bernard Van der Lande .2007, "Breakthroughs in the European Mobile Payment Market"

[53] Consultative Group to Assist the Poor (CGAP), 2006 "Mobile phone banking and low- income customers : evidence from South Africa,",

[54] Ivatury, Gautam. 2006. "Using Technology to Build Inclusive Financial Systems." CGAP.

[55] M. Suoranta and M. Mattila. 2004,"Mobile banking and consumer behavior: new insights into the diffusion pattern,"

[56] Jitendra Balani, Prabir Barooah, Sakshi Chadha and Raj Kumar," Lessons from the Costing Study on BC Networks", Microsave India

\section{Author Profile}

Punitha Ponnuraj has around 7 years of experience in process and domain consulting in IT products and services industry. Presently, she is pursuing Ph.D. from University of Mysore and working as a Consultant handling projects for Indian clients at Infosys Ltd.

Dr. Manasa Nagabhushanam has over 10 years of experience in handling research and consulting assignments from corporates, Government and other organizations. She has contributed as a Dean of Amity Global Business School and Director of PES-IUP MBA Program in Bangalore, Karnataka. Presently she has set up AnalyZ Research Solutions which provides Market Research support and Analytics solutions 